\title{
The Jewish Spirit of Contract and Its Implications on Chinese Education*
}

\author{
Quanmin Xin \\ Shandong Technology and Business University \\ Yantai, China
}

\author{
Yumeng Xin \\ Sichuan International Studies University \\ Chongqing, China
}

\begin{abstract}
China does not lack rules, but lack respect for rules, especially the spirit of law. In contrast, Jews, who value covenant or the spirit of contract to the utmost, can inspire the Chinese people to some extent. Jewish covenant is inherently and closely related to Jewish monotheism, in which there exists only one God, who not only made the world but also made rules for the world. But in China, the general public believes in polytheism, pantheism or atheism, and atheism is dominant in China, which means the formation of the spirit of contract is not an easy job. The cornerstone of the spirit of contract is belief. Therefore, we must focus on strengthening the cultivation of faith in the process of education in China in order to strengthen the spirit of rules, especially the spirit of law. Only in this way, the spirit of contract will take root in China, and the spirit of law will flourish in China.
\end{abstract}

Keywords - the spirit of contract; Jews; Chinese; education; faith; spirit of law

\section{INTRODUCTION}

Jews and Chinese are recognized as among the smartest people in the world. However, to stand out in the world, only by being clever is not enough. The Jewish spirit of contract has won the respect of the world for the Jews, and it is also worth the Chinese people's learning from them. This paper will first explore China's rule indifference, and then probe the Jewish spirit of contract and its root, and make a contrast and finally come to the conclusion.

\section{CHINA'S RULE INDIFFERENCE}

One of the most common problems in China is the indifference to rules. For example, pedestrians have "Chinese- style of crossing road", which means that some Chinese people collectively disobey traffic rules. Among drivers, there exists the phenomenon called "Chinese-style driving", where lots of drivers disregard traffic rules: Even on the zebra line, motor vehicles rarely yield to pedestrians, which is against the traffic law. It was reported that one day the police director of Shanghai crossed the street in Shanghai in plain clothes and a car yielded to him and gave way to him. He could not help exclaiming to the press: "Today a car yielded to me when I was crossing the street. I felt as if I was crossing the street in a foreign country, not in China."[1] In

*This paper is sponsored as a Teaching Reform Project by Shandong Provincial Education Department. It is a phased research achievement of The Optimization of College English Classroom Teaching Effectiveness Based on the Output Guidance Method (C2016M056).
2016 Hangzhou won heartfelt praise from home and abroad not only because the G20 summit was held there, but also because the drivers' courtesy to pedestrians. It is already a common and moving scene in the streets of Hangzhou for motor vehicles to yield to pedestrians, while in most places in China, this scene is still rarely seen. Traffic rules such as following the lights, and yielding to pedestrians on zebra crossing can be said to be well-known to every Chinese, but in fact the general public usually choose to disregard such rules. In fact, there is a clear regulation about road traffic "People's Republic of China Road Traffic Safety Law" clearly stipulates: "The traffic lights are made up of red light, green light and yellow light. The red light indicates that the traffic is forbidden, the green light is allowed to pass, and the yellow light is a warning." "When motor vehicles are passing through the crosswalk, the driver shall reduce speed; when pedestrians are passing the crosswalk, a motor vehicle should stop and yield to them. When there are no traffic lights on the road, drivers should yield to a pedestrian crossing the road. "[2] However, traffic rule indifference on the part of pedestrians and motor vehicle drivers led to brutal traffic accidents in China. According to the Ministry of Public Security Traffic Management Bureau news published in the "Legal Daily" in 2017 , "over the past 3 years, on zebra crossings 14 thousand traffic accidents occurred between motor vehicles and pedestrians, killing 3898 people. The accidents were mainly due to the dim awareness of the traffic participants in violation of laws and regulations for the traffic, i.e. motor vehicles passing through the crossing did not yield to pedestrians, or pedestrians disobeyed red light. From the statistics, accidents caused by not yielding to pedestrians on zebra crossings accounted for $90 \%$ of all traffic accidents in China." [3]

Chinese people's indifference to rules has a long history. For example, the popular story of Tian Ji Horse Racing is a typical example of the disdain of rules. The rules of horse racing are: horses are classified into three categories: the best, better and good. Each horse can only race with horses from the same category. Tian Ji broke the rules and used a horse from the good category to race with the best horse and lost the first game, but won the other two games by using his best horse and better horse against his opponent's better horse and good horse respectively. Tian Ji has been a typical and notorious example of disobeying rules, but ironically, his example has been passed on from generation to generation and praised as a good example. This profoundly reveals that 
the ancient officialdom and the general public are generally lacking the spirit of rules and contracts and they identify with the false behavior of deception. Yan Fu, China's outstanding educator, translator and Modern Enlightenment thinker, pointed out: "The evils in China begin with deception and end with shamelessness." [4] After comparing between Chinese and western entrepreneurs, Wang Shi, a contemporary famous entrepreneur, sharply pointed out: "In fact Chinese do not lack credibility", "It is the spirit of contract that Chinese people lack."[5]

\section{THE JEWISH SPIRIT OF CONTRACT}

A contract is an agreement between parties regarding the sale, mortgage, lease or other relations, which in form can be divided into textual contracts and spiritual contracts. The contracting parties may be between God and man, man and man, or even humans and animals, for example, between husband and wife, between different ethnic groups, between countries, between the rulers and the people, and one of the most important contracts is between God and human beings.

The spirit of contract originates from the Western religion, and the core is freedom, equality and trustworthiness, all of which are inseparable from religion. The spirit of contract is the mainstream of Western civilization. When talking about the spirit of contract, one cannot help thinking of the Jews. The Jewish concept of contract enjoys a long history, which is embodied in its classic Hebrew Bible( also known as the Old Testament) and the Talmud. The trustworthiness and the spirit of contract of the Jewish people are the model of the world. The "covenant" is a very critical concept in the Jewish culture, and the core of the Jewish culture is the covenant with God. Judaism holds that Jews are "chosen people", a special group chosen by God from many ethnic groups in the world. Their particularity lies in the "covenant" between God and Jews.

The covenant between God and Jews is the core of Jewish culture, including many contracts, such as the contract between God and the Jewish ancestor Abraham, which establishes the special relationship between God and Jewish people. The covenant between God and Moses stipulates all aspects of Jewish life. For thousands of years, the concept of contract has been the most important link to maintain the Jewish people even though the Jews have been scattered around the world for thousands of years.

Jews consider themselves "the chosen people of God" and are called "the people of the contract". The Jews believe that the covenant between God and man is a solemn agreement between God and man, which not only restricts human beings, but also restrains God. God is our covenantobeying God, and God strictly demands his people to obey the covenant. It was this spirit of contract that gave birth to the trustworthiness of the Jews and even the Westerners.

The Jews keep in mind the contract in all aspects of social life, and they also keep the contract in business. The Jewish spirit of contract is famous all over the world. The Jews believe that the contract is an agreement between God and man, so any breach of contract is blasphemy. Even the verbal agreement is binding enough, because "God can hear it."

The Jews' faith in the contract was carried out almost to the extreme, to a surprising extent. In business negotiations, the Jews argue bitterly with the opponent in every detail and they never give in easily, but once the two parties reach an agreement, and sign a contract, and the contractual relationship is established, each party must abide by the contract even if that may cause heavy losses to the Jews. The Jews, no doubt, will abide by the contract naturally, willingly and without hesitation.

Tamud, another Jewish classic second only to the Hebrew Bible, is the "guide of Jewish faith and of religious services"[6]. Rabbi Adin Steinsaltz, an authority in the research of Talmud, speaks highly of the Tamud: "if the Bible (the" Old Testament ") is the cornerstone of Judaism, Tamud is a main pillar standing in the center of the foundation by supporting the building of Jewish spirit and wisdom. In many ways, Talmud is the most important book of Jewish culture and the source of the life and creativity of the Jewish nation. "[7] Famous sayings from Talmud include: "Abide by the contract, respect the contract, you will get more than respect." "The law is relative, the politics is relative, the national boundary is relative, even the morality is relative, only the contract that you promise to abide by is eternal." "A contract is a covenant with God". [8]

Jews not only abide by the contract themselves, but also require the people they associate with to keep their promises and abide by the contract, because from their experience Jewish people know, "to give one's opponent a benevolent concession is to be cruel to themselves."[9]

\section{JEWISH FAITH AND CHINESE FAITH}

The concept of "covenant" is the core of Judaism. It, together with the Jewish belief of one God, constitutes the basis of Judaism.[10]

It can be said that the Jewish monotheism is the foundation of the Jewish spirit of contract. Only out of the fear of God have the Jewish people developed their sense of fear to covenant between God and man, and between man and man.

"The Jewish spirit of covenant and monotheism is closely related and inseparable."[11] Two important Jewish beliefs are Monotheism and the spirit of contract. Monotheism provides rules and regulations for the Jewish people to avoid the state of disorder, and the spirit of contract equips them with the most important quality in the social life, especially in business.

According to the Hebrew Bible, Abraham, the ancestor of the Jews, abandoned the worship of polytheism and focused on the worship of one God. Through the covenant with God, Abraham laid the foundation for Jewish monotheism. In Judaism, the covenant is as follows: God, the one and only true God, and the embodiment of the most high, will dominate the fate of Jews; in the meantime, God promises to undertake the commitment and responsibility to protect the survival and development of the Jews; on the 
other hand, the Jews should fulfill their responsibility of the fear of God, such as circumcision etc..

The existing beliefs of the world, according to the number of Gods worshiped, can be divided into atheism, monotheism, polytheism and pantheism. Atheism such as communism holds that there exists no God. Monotheists hold that there exists only one God, which is not drastically different from polytheism, and from pantheism and deism. Nowadays the existing monotheism, generally called the Abrahamic religions, all of which regard Abraham as their ancestor mainly includes: Judaism, Christianity and Islam (in time order). The relationship between the three religions is very close. In fact, both Christianity and Islam originated from Judaism.

As the world's earliest monotheism, Judaism regards monotheism as the core of their belief: "1, God, the Creator, created and masters of the universe and all creatures. 2, the creator is one and only God. 3, God created everything, invisible and invisible. 4, the Creator is the first and the last. 5 , the Creator is the only Lord to be worshiped, and there is nothing else to be worshiped. 6, all that was taught by prophets are authentic. 7, Moses was the greatest of the prophets. 8, The law has been passed to Moses by God, and there is no change. 9, the law should not be changed. 10, Creator has a keen insight into all the thoughts and actions of the world. 11, Lord, the Creator, will reward whoever obeys the law, and punish the trampling of the law. 12, The Messiah, the Savior, is bound to come. It should be expected each day and no one should slack. 13, a man will be resurrected after death."[12]

"Monotheism" was first put forward and later observed by the Jews, so Judaism is considered to be the earliest monotheism. Monotheism is the core of Judaism, and Judaism's most important contribution to human culture.[13]

$\mathrm{Xu}$ Xin, a famous contemporary Jewish scholar in China, commented on the thought of the Jewish God: "the idea of one God endows the world with purpose and meaning, which makes the world wake up from confusion and set up moral norms and codes of conduct for people." [14]Some scholars have pointed out that God is the highest invention of human intelligence.[15] In the eighteenth century, Voltaire, the French bourgeois Enlightenment scholar, said: "even if there were no God in the world, it would be absolutely necessary to create a God."[16] God is indeed good for the health of the human soul, so it is more reasonable to believe in God than not to believe in God.

In Judaism, God is sacred. It is incomparable, omnipresent and omniscient. It is unified, unique, timeless, invisible and omnipotent. There exists no other deity except God. Man should be in awe of God and love God.

Things are quite different in China. In China, there is a lack of awe - inspiring God among the general public. The popular belief is either atheism, or polytheism or pantheism or deism. In the eyes of those Chinese who believe there exists gods, the number of Gods is beyond count. In accordance with the religious view, and judged from the track of the development of world religions, pantheism and polytheism are the early stages of the development of religion. In China, the common phenomenon is not that human beings were created by God, but that the Gods have been and will be created by human beings. The mainstream folk beliefs are Confucianism, Taoism and Buddhism, and in some cases, the mixture of the three. There exist many socalled three-religion temples in which Buddha, Confucius, and Lao Tzu are worshiped side by side at the same time. Though the gods are numerous, they are generally not deterrent to Chinese people, so ordinary Chinese do not reverently revere the gods as Jews fear God.

The Chinese belief is often pragmatic and utilitarian. The religious beliefs of the Chinese people are represented by "sometimes believing, sometimes unbelieving, believing when people need help from gods and not believing when such need does not exist." Only when they are in trouble and in need of help from gods will the general public go to worship gods, no matter whether the gods are Confucius, Lao Tze, Buddha, or any ghosts. For example, they will remember to pray and ask favor of gods when they encounter difficulties in life, such as family discord, physical discomfort, promotion, or wealth barrier. When they want to make a fortune, they will choose to worship the God of wealth; when they want to have children, they will worship the goddess who is in charge of child-bearing; when then want to go to school, they will pray to "God of Learning"; nowadays, China has entered the automobile society, and a new god in charge of safe driving was created to bless drivers. The purpose of Chinese belief is very practical, and obviously utilitarian. In the Chinese mind, although various gods have a certain authority, but their authority is relative and restricted in their field and can be counteracted by other gods, making their power greatly reduced. Therefore, the general public in China does not have the same fear to gods as the fear to God in Judaism.

Christine Hayes, a famous atheist and professor of religion at Yale University, objectively commented on the progress of the evolution from polytheism to monotheism: "God in monotheism, theologically speaking, functions more thoroughly than the decentralized gods in polytheism, and is a more advanced form. In terms of philosophy or from a political point of view, monotheism is more progressive than polytheism." [17]

\section{CONCLUSION}

If God is not to be feared, what is the point of fearing rules and contracts? From this point of view, there remains a long way to go for the Chinese people to cultivate the spirit of covenant. Therefore, attention must be paid to the education of the spirit of contract to students so that they can make due contribution to the overall development of the society.

First of all, it is necessary to foster and strengthen the students' faith. Xi Jinping, Chinese president and general secretary of Chinese Communist Party, pointed out the importance of faith, "The more faithful the Chinese people are, the more hopeful the nation will be, and the more powerful the state will be."[18] In other words, if the 
Chinese people have no faith or lack faith, our nation will be hopeless, and our country can only be outwardly strong but inwardly weak.

Faith, as an important cornerstone for national rejuvenation and national prosperity, must be attached great importance to. The current socialist core values education is an important step to build the cornerstone of the whole social belief.

Secondly, we must strengthen the indoctrination of the students' spirit of contract and their spirit of law. In a broad sense, the content of the spirit of contract is very rich, and the spirit of law is one of the important contents. The society is in great need of qualified workers, who must have the sense of respect for law and respect for contract. Therefore, in the daily teaching, the cultivation of the students' spirit of contract, especially the spirit of law, must be strengthened.

\section{REFERENCES}

[1] Shanghai Municipal Public Security Bureau Director, Bai Shaokang: Today, there is a courtesy car for pedestrians. [DB/OL].http://www.guancha.cn/society/2016_05_10_359790.shtml.

[2] "People's Republic of China Road Traffic Safety Law" [DB/OL].http://www.bjjtgl.gov.cn/jgj/fl/205308/index.html.

[3] Liu Ziyang. $90 \%$ of all road accidents happened on zebra crossing over the past three years [N]. "Legal Daily" June 19, 2017 third edition.

[4] Yan Fu. National Salvation Theory [M]. Beijing: Zhonghua Book Company, 1986:53.

[5] Wang Shi: Chinese entrepreneurs lack the spirit of contract [DB/OL].http://money.163.com/12/0829/10/8A2MQAPU00253G87_ all.html.

[6] Pan Guang. "Jewish Studies in Chinese -- thirty-year Review: 19782008" [M]. Shanghai: Shanghai Social Science Press 2008:13.

[7] Adin Steinsaltz. The Essential Talmud [M]. New York 1976:3, quoted from Pan Guang as "the Jewish Civilization" [M]. Fuzhou: Fujian Education Press, 2008:56.

[8] Wen Dao. "The Talmud: Jewish Wisdom Book"[M]. Shenyang: Wanjuan Publishing Company, 2015: 128.

[9] Xia Ziyan. The Secret in Talmud [M]. Beijing: Chinese Women Press, 2015.05:105.

[10] Jia Yanbin. "Covenant", "The Basic Concepts of Judaism" . Nanjing: Jiangsu People's Publishing House, 2013:64.

[11] Xu Xin. "Jewish Cultural History" (Second Edition) [M]. Beijing: Peking University Press, 2011:79.

[12] Xu Guobin. Western Cultural Essentials [M]. Guangzhou: South China University of Technology Press, 2009:413.

[13] Xu Xin. The Basic Concept of Judaism [M]. Nanjing: Jiangsu People's Publishing House, 2013:1.

[14] Xu Xin. Jewish Culture History (Second Edition) [M]. Beijing: Peking University Press, 2011:73.

[15] Gao Weiguang. Western Religious Culture and Literature [M]. Beijing: Chinese Social Sciences Press, 2012:39.

[16] Gu Chunde, Lv Shilun. The Western History of Political and Legal Thought $[\mathrm{M}]$. Shenyang: Liaoning People's Publishing House, 1986:347.

[17] Is monotheism more progressive than polytheism? Why? [DB/OL].Http://www.zhihu.com/question/38975133? Sort=created.

[18] Xi Jinping: More Faithful, More Hopeful, and More Powerful [DB/OL]. http://politics.people.com.cn/n/2015/0228/c102426613960.html. 